\title{
Juveniles and undersized fish in small-scale fisheries: gillnets are not less implied than trawling
}

\author{
Paulo de Tarso da Cunha Chaves*
}

Zoology Department, Federal University of Paraná, PO Box 19020, Code 81531-980 - Curitiba, Brazil. ORCID Paulo de Tarso da Cunha Chaves (D) https://orcid.org/0000-0001-6393-8256

Marine and Fishery Sciences MAFIS

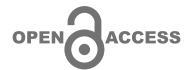

*Correspondence: ptchaves@ufpr.br

Received: 10 August 2021 Accepted: 16 November 2021

ISSN 2683-7595 (print) ISSN 2683-7951 (online)

https://ojs.inidep.edu.ar

Journal of the Instituto Nacional de Investigación y Desarrollo Pesquero (INIDEP)

This work is licensed under a $\mathrm{Cr}$ Commons AttributionNonCommercial-ShareAlike 4.0 International License

\begin{abstract}
Of particular concern in commercial fishing catch is 'size bycatch', i.e. the death of early stages of resources that would reach a marketable value when they turn into adults. This event is frequently associated with trawling because of the lower size selectivity of this gear as compared to gillnets. However, this is expected when small-scale fisheries (SSF) employ gillnets simultaneously in setnets + driftnets that mix multiple mesh sizes. This work analyzes fishing captures and compares characteristics of fish catch from gillnets and trawlers with respect to size at first maturation, legal size of capture, and expected discards. Data were obtained from 2007-2021 for SSF in Southern Brazil. A total of 112 fish species were represented in the data. Gillnets exploited fewer species than trawlers; however, most of these constitute fishing resources in the study region. Of the 19 species whose maturation size is known, nine occurred in gillnets as juveniles, and of the 14 species for which the legal size of capture is established, seven occurred in gillnets in prohibited sizes. Gillnets and trawlers presented size bycatch and affected different species between them, with four resources that were present in bycatch from both gillnets and trawlers. The broad range of mesh sizes employed by SSF warns of the discarding of undersized captures, and stresses the importance of policies addressing gillnet management.
\end{abstract}

Key words: Artisanal fisheries, bycatch, fisheries management, Brazil.

Juveniles y peces pequeños en la pesca artesanal: las redes de enmalle no están menos implicadas que la pesca de arrastre

RESUMEN. De particular preocupación en la pesca comercial es el tamaño de los organismos en la captura incidental, es decir, la muerte de las primeras etapas de los recursos que alcanzarían un valor comercial cuando se conviertan en adultos. Este evento se asocia frecuentemente con la pesca de arrastre debido a la menor selectividad de tamaño de este arte en comparación con las redes de enmalle. Sin embargo, esto es esperable cuando en las pesquerías de pequeña escala (PPE) se emplean redes de enmalle simultáneamente en las redes de arrastre + redes de deriva que mezclan varios tamaños de malla. Este trabajo analiza las capturas pesqueras y compara las características de las capturas de peces en las redes de enmalle y en los arrastreros con respecto al tamaño de primera madurez, el tamaño legal de la captura y los descartes esperados. Se obtuvieron datos de 2007-2021 para la PPE en el sur de Brasil. En los datos estuvieron representadas un total de 112 especies de peces. Las redes de enmalle explotaron menos especies que los arrastreros; sin embargo, la mayoría de estos constituyeron recursos pesqueros en la región de estudio. De las 19 especies cuyo tamaño de maduración se conoce, nueve se encontraron en las redes de enmalle como juveniles, y de las 14 especies para las que se establece el tamaño legal de captura, siete se encontraron en redes de enmalle en tamaños prohibidos. Las redes de enmalle y los arrastreros presentaron captura incidental de tamaño y afectaron a diferentes especies en forma conjunta, con cuatro recursos que estuvieron pre- 
sentes en la captura incidental tanto de redes de enmalle como de arrastreros. La amplia gama de tamaños de malla empleados por la PPE es una advertencia sobre el descarte de capturas de tamaño pequeño y enfatiza la importancia de políticas que aborden el manejo de las redes de enmalle.

Palabras clave: Pesquería artesanal, captura incidental, manejo pesquero, Brasil.

\section{INTRODUCTION}

Small-scale fisheries (SSF) differ from largescale fisheries with respect to several technical, economic, and social attributes. From a conservation perspective, fishing effort in SSF is often more tolerable and catches are less focused on a few stocks. By using passive gears such as hand lines, fish traps, and gillnets, SSF tends to optimize human work and reduce fuel consumption (FAO 2016). These gears show higher capture selectivity with respect to species and individual size as compared to trawl nets (Armstrong et al. 1990; Wolff et al. 2015), another gear employed by SSF fisheries as well as large-scale fisheries (Misund et al. 2002; Santurtún et al. 2014). In comparative studies between gillnets and trawling, Olin and Malinen (2003) found that in South Finland fish smaller than $5 \mathrm{~cm}$ corresponded to $51 \%$ of trawler captures, while they corresponded to only $1 \%$ of gillnet captures; and Huse et al. (2000) found that the mean length of cod caught in gillnets on the Norway coast was approximately $17 \mathrm{~cm}$ larger than those caught by trawl nets. Trawling is known to generate bycatch (SilvaJúnior et al. 2015; Cardoso et al. 2021). This promotes design adaptations to reduce the capture and consequent discarding of non-target species and individuals (Alarcón Vélez et al. 2014; Freiría et al. 2014), and strategies as in the penaeid fisheries off Iran, where experiments are being conducted to replace trawl nets with gillnets (Hout et al. 2021).

A particular concern regarding incidental captures is 'size bycatch', i.e. the death of juvenile stages of fish, crustaceans, and cephalopods that would reach a satisfactory price for selling as adults. In Southern Brazil, size bycatch from trawlers includes small individuals of marketable species, such as Micropogonias furnieri (3\% in weight), Umbrina canosai (7\%), and Cynoscion guatucupa (14\%) (Cardoso et al. 2021). Apart from the economic loss, discarding resources that are not targeted or are below the permitted capture size constitutes a sensitive problem because of its ecological and ethical implications (Santurtún et al. 2014).

Gillnets incidentally capture charismatic animals, such as turtles, birds, and mammals (Cheng and Tien-Hsi 1997; Cardoso et al. 2011; FAO 2020). These captures do not produce discarding of size bycatch origin (Santurtún et al. 2014), probably because, as verified in the haddock and the Arctic cod fisheries in Finland (Huse et al. 2000), rates of young-adults in catches are lower with gillnets than with trawls and longlines. However, gillnets also show size bycatch that varies between mesh sizes, as observed in a fish assemblage in a Brazilian lake (immature versus mature individuals, Silvano et al. 2016), or with depths of operation, as observed in the whiting fisheries in the Black Sea (Kalayci and Yeşilçiçek 2014).

Each mesh size is selective for a particular morphology (Armstrong et al. 1990; Reis and Pawson 1999). Gillnets mixing different meshes are potentially efficient in capturing a larger spectrum of fish morphologies, widening the range of vulnerable sizes for capture. The use of setnets and driftnets is common in SSF, particularly in tropical waters, where many target resources share a common area (Alves et al. 2012; Wolff et al. 2015). The present work investigates how the employment of multiple mesh sizes in a restricted 
area results in higher size diversity in the catch, comparatively to trawling. If such heterogeneity includes fish with no marketable value or prohibited species and size classes, they are discarded on board or after landing. Is it plausible to suppose that, in such conditions, gillnets capture juveniles and undersized fish at a not-smaller scale than trawl, and are also harmful for fisheries sustainability?

Along the littoral coast of Southern Brazil, in shallow waters up to $30 \mathrm{~m}$, gillnets and trawl nets are the main fishing gears employed by SSF (Chaves and Robert 2003). Gillnets are deployed from the bottom to the surface and target several teleosts and chondrichthyan species. Trawling is performed on the bottom and targets shrimp. Both gears register incidental captures, mainly fish and invertebrates. While the small meshes used for trawling $(1-2 \mathrm{~cm})$ catch an important abundance of benthic fauna, including small fish (Pina and Chaves 2009; Chaves and Silva 2019), the larger meshes used for gillnets $(5-20 \mathrm{~cm})$ retain a considerable number of non-target fish
(Chaves et al. 2019; Afonso and Chaves 2021). This study analyzes the fish size in trawling and gillnets captures, comparing the two gears with respect to three parameters: legal size of capture, size at first maturation, and expected discards. Does trawling affect more undersized (legal capture and/or first maturation) species than gillnets? With respect to legal capture and first maturation, what is the species performance of each gear? What target resources occur as bycatch in these gears?

\section{MATERIALS AND METHODS}

The study area is located in Southern Brazil, on the coasts of Parana and Santa Catarina states, $25^{\circ} 30^{\prime} \mathrm{S}-26^{\circ} 10^{\prime} \mathrm{S} ; 48^{\circ} 10^{\prime} \mathrm{S}-48^{\circ} 40^{\prime} \mathrm{W}$. This corresponds to the fishing area of three SSF communities: Matinhos, Itapoa, and São Francisco do Sul (Figure 1). The fishing fleet consists of between 30 and 50 fiberglass canoes in each

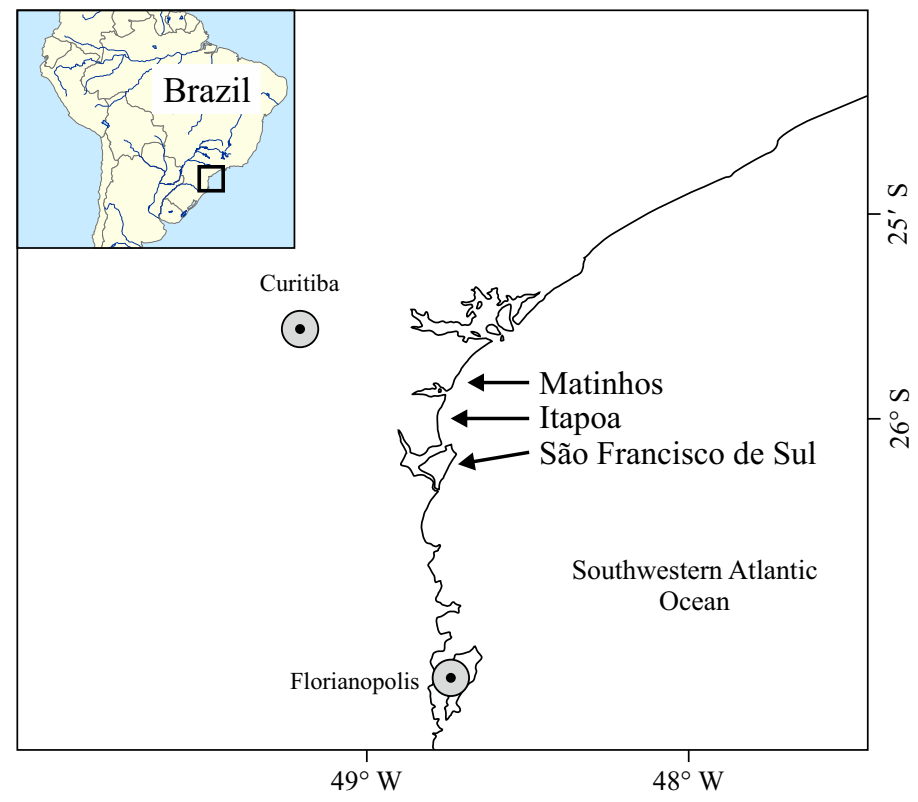

Figure 1. Study area (small square) on Southern Brazilian coast and location of fishing communities of Matinhos, Itapoa, and São Francisco do Sul (arrows). 
community, measuring 8-12 $\mathrm{m}$, all motorized with $<60$ HP. They are equipped with a gillnet and/or with bottom trawling gear. Fishers perform one-day trip, but gillnets fish for up to six days continuously. In trawling, two nets are simultaneously pulled by canoes at depths of 8$15 \mathrm{~m}$ in successive hauls during 6-8 $\mathrm{h}$ per day. The mesh size at the codend is $1-2 \mathrm{~cm}$ between opposite knots, and the target resource is the seabob shrimp Xiphopenaeus kroyeri. Gillnets have a height of up to $20 \mathrm{~m}$ and a length of a few hundred to four thousand meters. They are fixed to the bottom or drifting at depths of 10-30 m. Mesh sizes are diverse, typically 5, 7, 9, 11, 12, and $20 \mathrm{~cm}$ between opposite knots, depending on the target resource, sharks and teleosts. The latter primarily belong to Mugilidae, Scombridae, Pomatomidae, Sciaenidae, and Pleuronectiformes. Technical specifications of trawl nets and gillnets used in the study area, target resources, and modes of operation are described by Chaves and Robert (2003), Nogueira et al. (2011), Chaves et al. (2019), and Afonso and Chaves (2021).

The range of total length (TL) by species and the minimum and maximum TL values were linked with gillnets or shrimp trawling. The sources used were: (i) previous works carried out in the study area from 2007-2016; fish were obtained by monitoring landings in the cited communities, or experimental cruises for academic research using boats and fishing gears routinely employed by them; and (ii) original data obtained by monitoring landings of the Matinhos fleet during 2020-2021. In experimental cruises, all individuals were measured, while in monitored landings individuals were accessed by chance. Because most of the sources did not discriminate between the mesh size of gillnets, they were considered as a single entity.

For each species, the largest TL landed by trawlers (Max. TL T) and/or the smallest TL landed by gillnetters (Min. TL G) were identified. These data were compared with two other specif- ic TL values: the minimum size of legal capture (TL C), and the average size at first maturation $\left(\mathrm{TL}_{50}\right)$, preferentially in this area or, when not available, in Brazil. When $\mathrm{TL}_{50}$ differed between sexes, the largest value was adopted. Values of TL C came from federal rules MMA 53/05 (MMA 2005) and IBAMA 83/06 (MMA 2006), while those of $\mathrm{TL}_{50}$ came from the literature.

Species of commercial interest in the study area were recognized after the findings of Chaves and Robert (2003), Chaves et al. (2019), and Afonso and Chaves (2021), and designated as fishing resources. Carcharhinus sp., Diplectrum sp., Paralichthys sp., and Sphyrna sp. refer to two or more species occurring in the study area and are not always recognized at species level. To simplify the representation of results, each genus was considered a single species.

\section{RESULTS}

Values of Max. TL T were compiled from 100 species and those of Min. TL G from 32 species. Overall, data on 112 species were compiled with more than $30 \%$ (42) constituting fishing resources in the study area (Table 1).

The number and weight of catches were not quantified, but data indicate that, all species considered, individuals $<100 \mathrm{~mm}$ were vulnerable almost exclusively to trawling, while those in the range of 100-300 $\mathrm{mm}$ were vulnerable to both trawling and gillnets. A few species were represented in trawl nets by individuals $>500 \mathrm{~mm}$ or occur in gillnets with individuals not smaller than $500 \mathrm{~mm}$ (Figure 2). Gears partially shared the ranges 36-940 $\mathrm{mm}$ for Max. TL T, and 110-720 mm for Min. TL G (Table 1). Most representative size classes corresponding to $>10 \%$ of frequency of occurrence confirmed significant captures by both gears of species within TLs 100-300 mm: Max. TL T at classes 110-230 mm, and Min. TL $\mathrm{G}$ at classes 110-270 mm (Figure 2). 


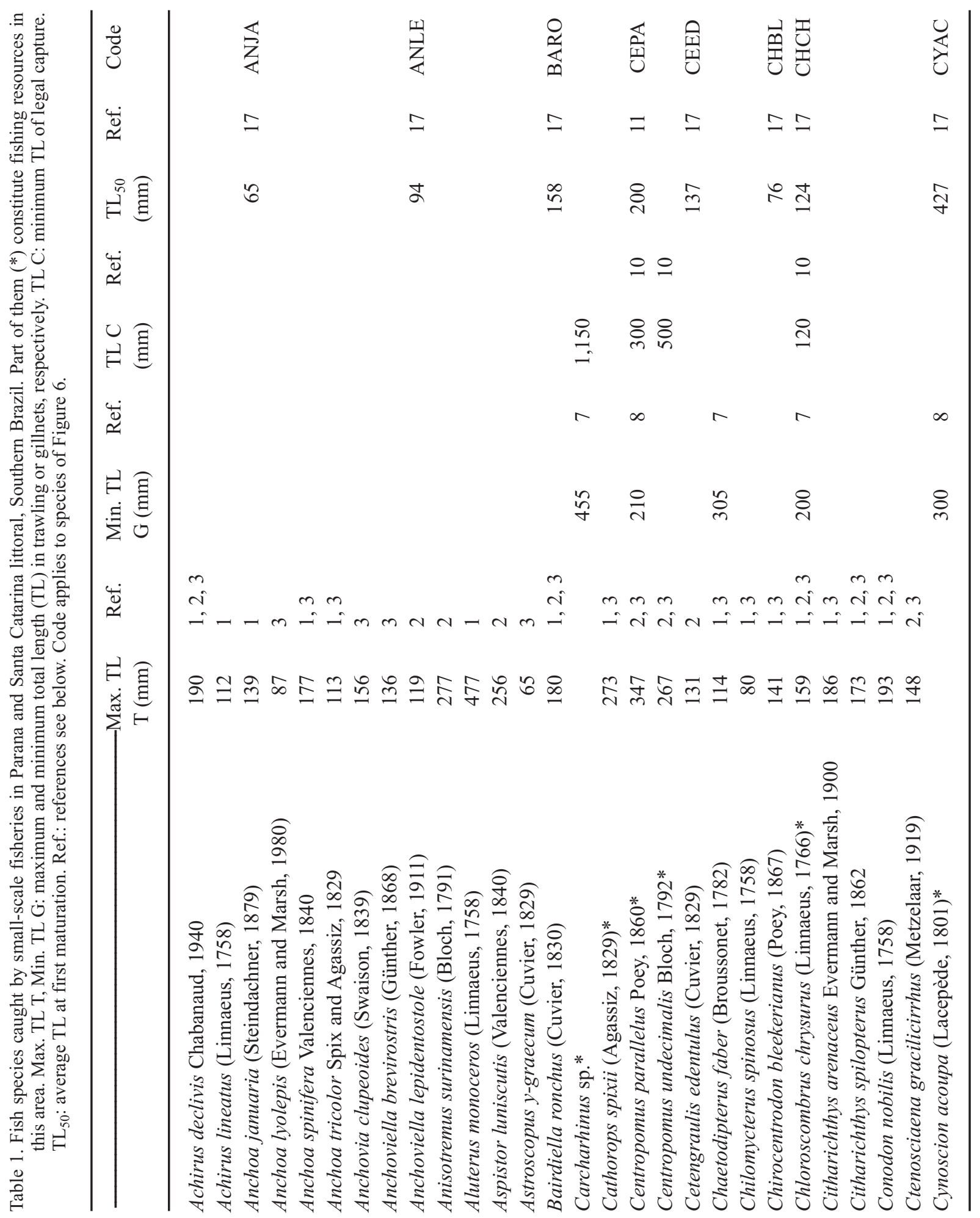




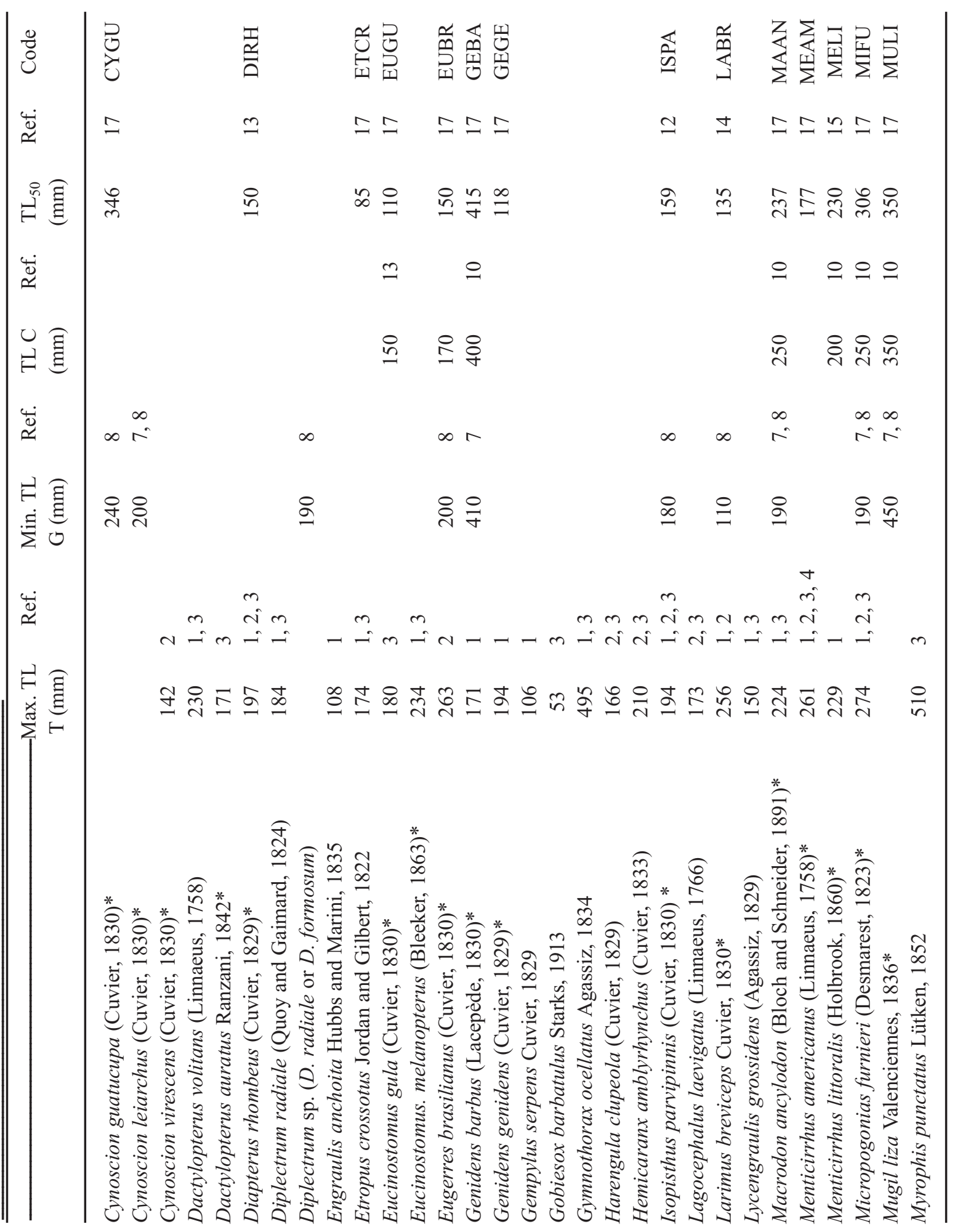




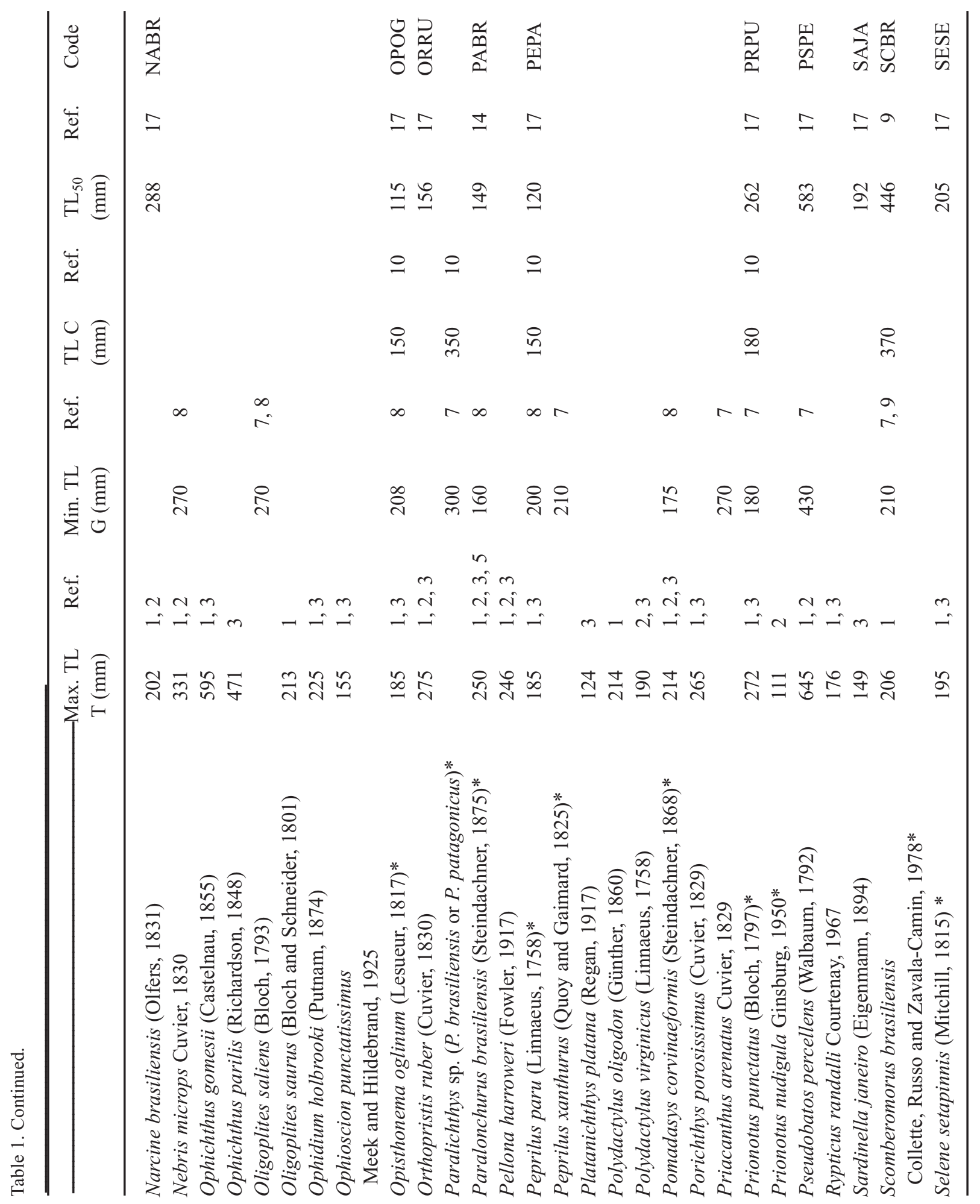




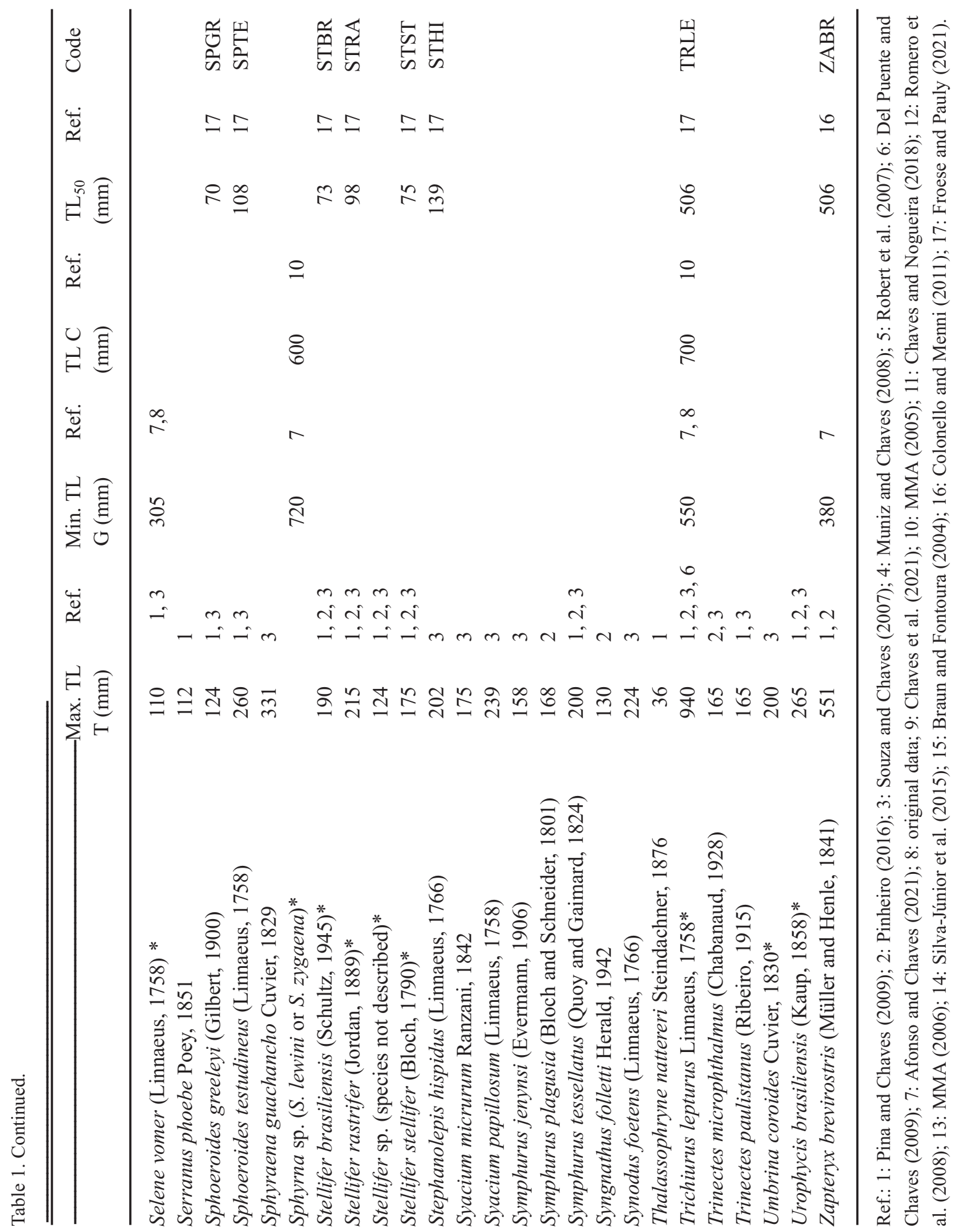




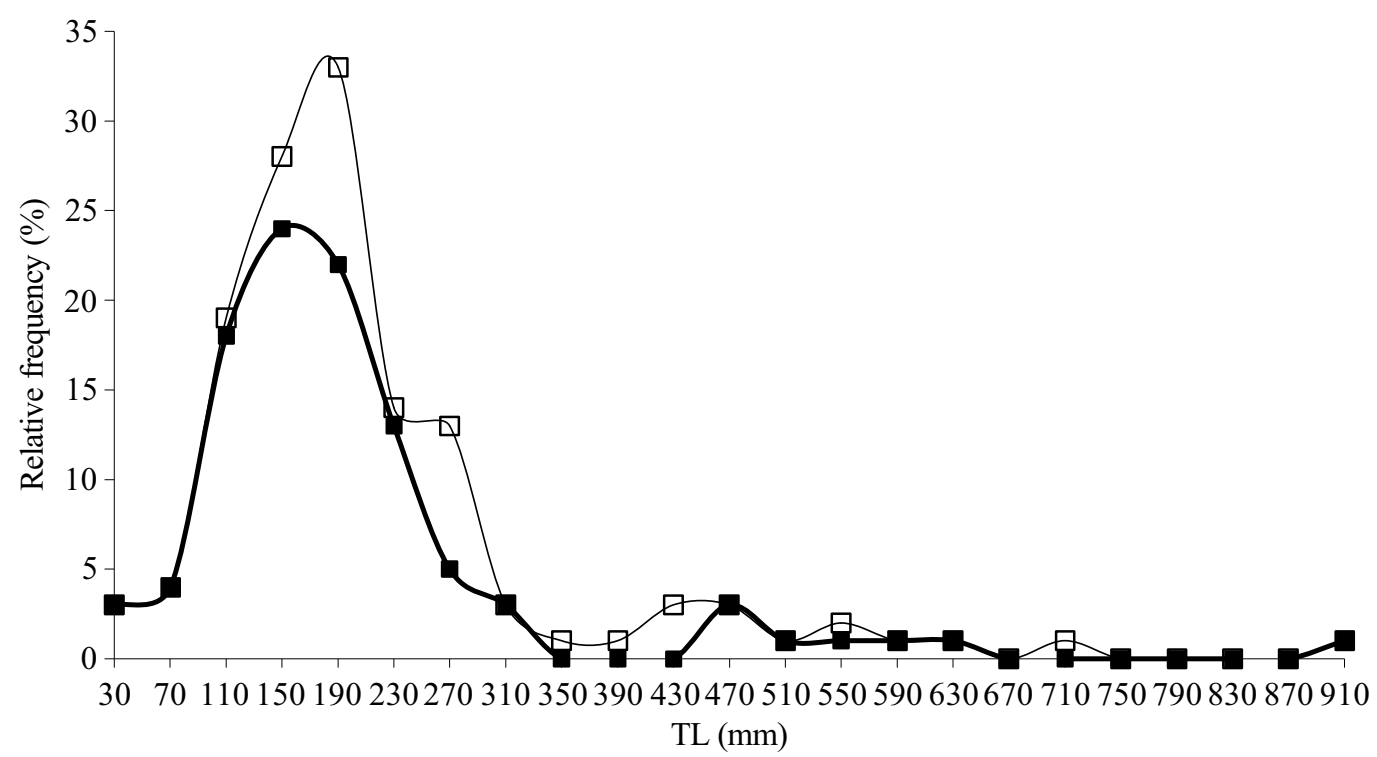

Figure 2. Relative frequencies of species $(\mathrm{N}=112)$ according to individual total length $(\mathrm{TL})$ registered in small-scale fisheries in Southern Brazil grouped in $40 \mathrm{~mm}$ size classes. Maximum TL in trawling: wide line, 100 species; minimum TL in gillnets: narrow line, 32 species.

Twenty species were common to both gears, and $70 \%$ of them had Max. TL T > Min. TL G (Figure 3). Species represented in trawling by individuals $<200 \mathrm{~mm}$ only contained Min. TL G $>$ Max. TL T. Conversely, individuals $>200 \mathrm{~mm}$ presented TL T $>$ Min. TL G (Figure 3).

Among the 20 species common to trawling and gillnets, 16 constitute fishing resources in the study area (Figure 4). Thirteen species, ten of which are fishing resources in the region, presented the relationship 'Max. TL T/Min. TL G' > 1.0. This reveals that trawling also acts on important sizes that are larger than the smallest individuals caught by gillnets. For five resources, Prionotus punctatus, Paralonchurus brasiliensis, Centropomus parallelus, Trichiurus lepturus, and Larimus breviceps, trawling catches individuals up to 1.52.3 times larger than the smallest ones caught by gillnets (Figure 4). The other 26 fishing resources were classified under trawling (18) or gillnets (8) (Table 1).

The minimum size of legal capture (TL C) was established for 18 fishing resources (Table 1). Trawling exploits 13 of these species. Nearly
$70 \%$ (9) presented the relationship 'Max. TL T/TL C' $>1$; however, it is expected that all 13 species have individuals caught with TL $<$ TL C. Gillnets exploited 14 resources; half of them presented the relationship 'Min. TL G/TL C'> 1, and prohibited sizes were probably not caught by gillnets. The other 50\% (seven resources) presented Min. TL G $<$ TL C and were vulnerable to being captured at prohibited sizes (Figure 5).

The average size at first maturation is known for 40 species (Table 1). Trawling exploited 37 of them. Nearly $75 \%$ (29) presented the relationship 'Max. TL T/TL ${ }_{50}$ ' > 1; however, it is expected that all 37 species caught individuals with $\mathrm{TL}<$ $\mathrm{TL}_{50}$. Gillnets exploited 19 species. Nearly 55\% of them presented the relationship 'Min TL $\mathrm{G} / \mathrm{TL}_{50}$ ' $>1$, and probably are not caught by gillnets before the first maturation. Conversely, $45 \%$ (9 species) presented Min TL $\mathrm{G}<\mathrm{TL}_{50}$ and were vulnerable to gillnets as juveniles (Figure 6).

For trawling, nearly $75 \%$ (19/25) of fishing resources analyzed for maturation size presented the relationship 'Max. TL T/TL 50 ' $>1$, but it is expected that all 25 resources caught individuals 


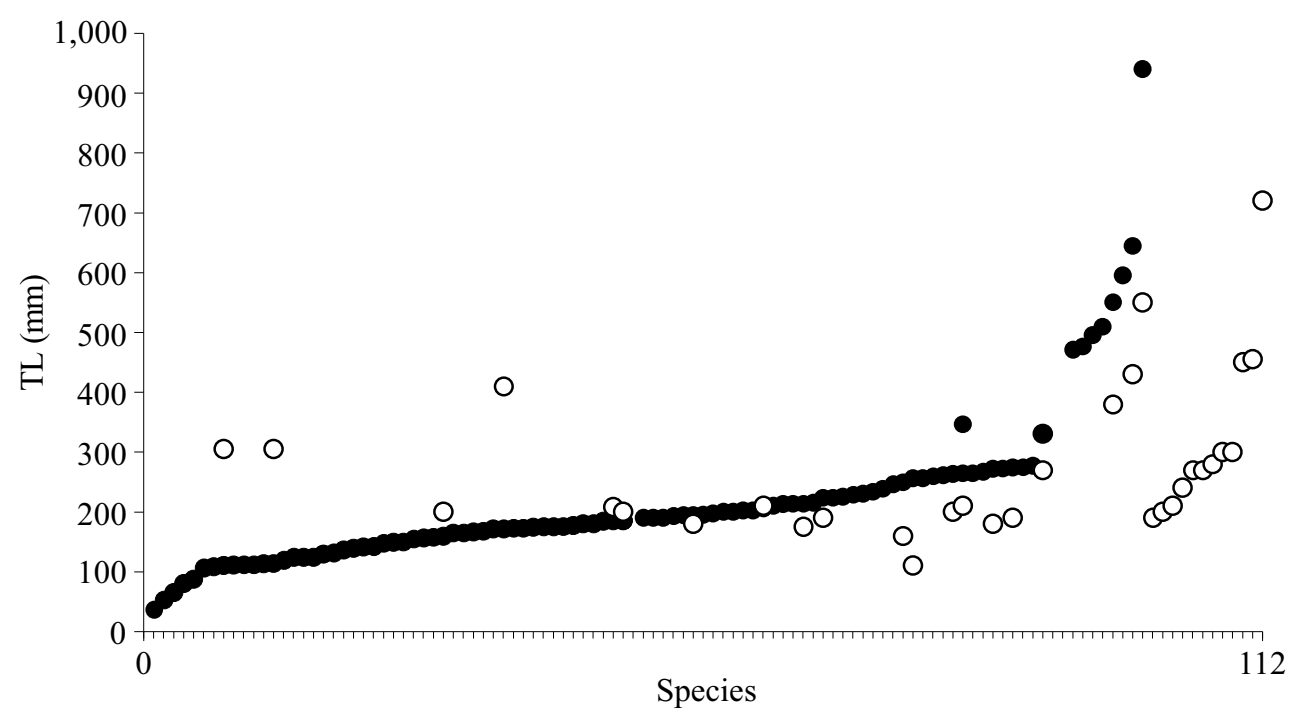

Figure 3. Distribution of values of maximum total length (TL) in trawling (dark circles) and/or of minimum total length in gillnets (white circles) of 112 species caught by small-scale fisheries in Southern Brazil.

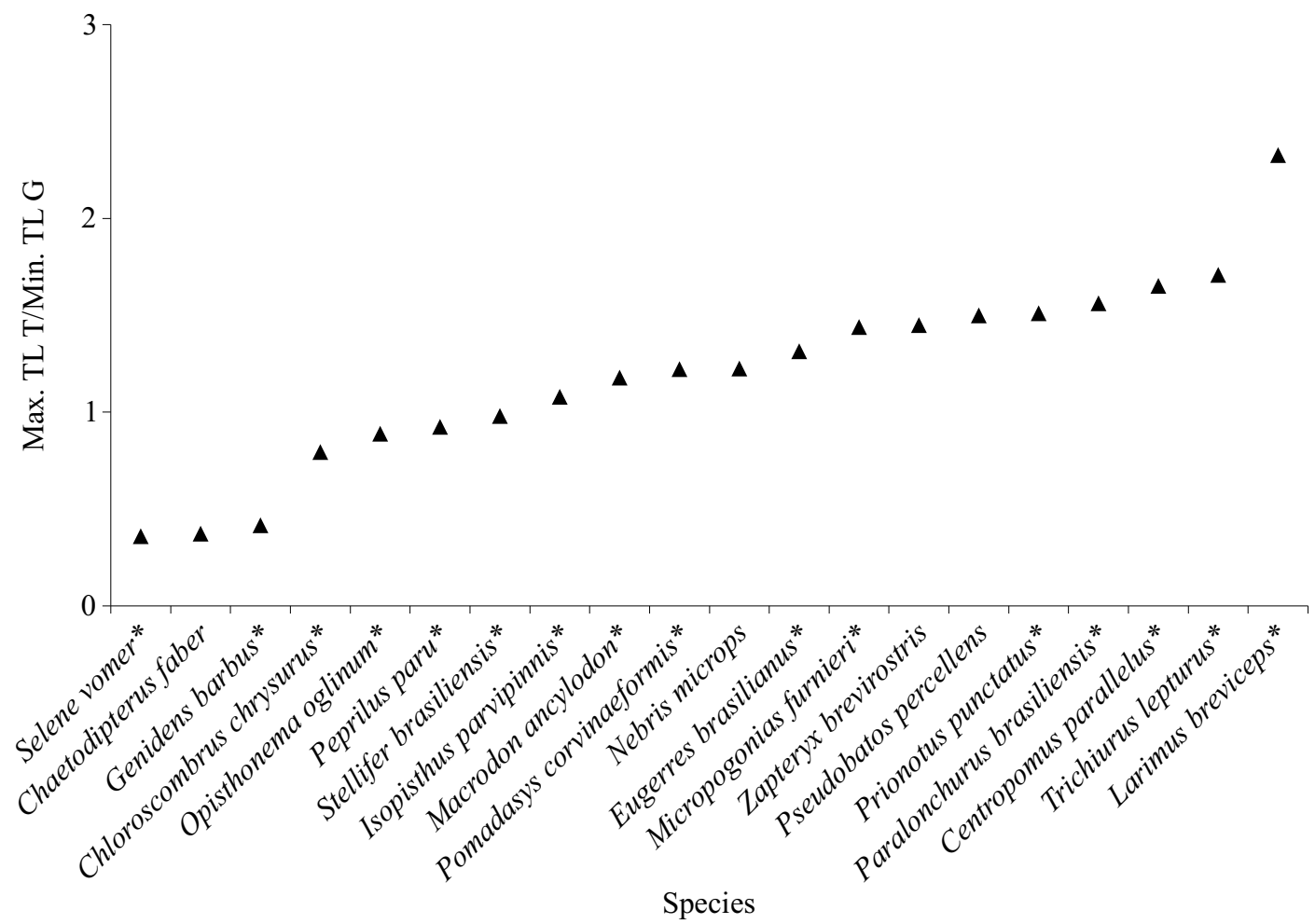

Figure 4. Species of common occurrence in both fishing gears (trawl nets and gillnets) in Southern Brazilian small-scale fisheries, and values of the relationship between the maximum total length in trawling (Max. TL T) and the minimum TL in gillnets (Min. TL G). *: species that constitute fishing resources in the study area. 


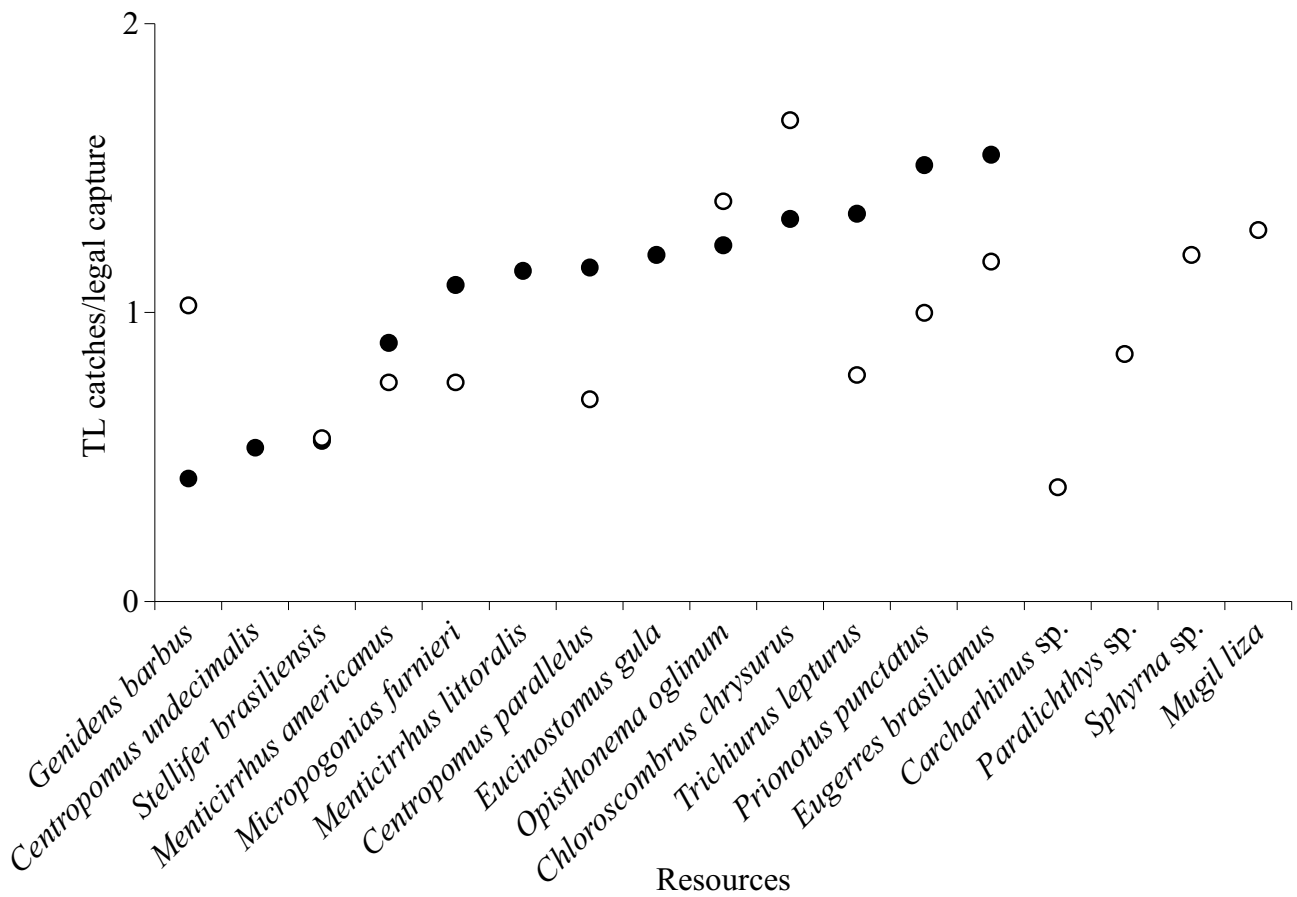

Figure 5. Relationship between total length (TL) in catches and TL of legal capture in resources exploited by small-scale fisheries in Southern Brazil. Dark circles indicate the maximum TL in trawling; white circles indicate the minimum TL in gillnets.

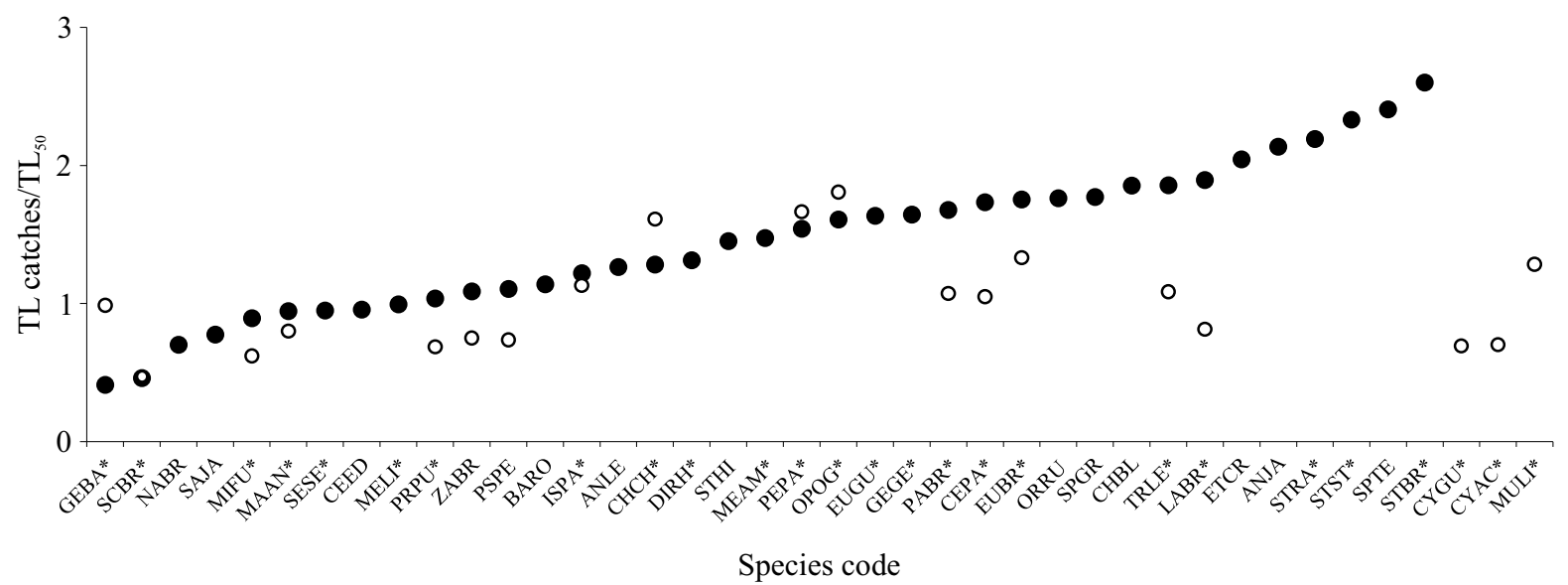

Figure 6. Relationship between total length (TL) in catches and average TL of maturation $\left(\mathrm{TL}_{50}\right)$ in species exploited by smallscale fisheries in Southern Brazil. Dark circles indicate the maximum TL in trawling; white circles indicate the minimum TL in gillnets. *: species that constitute fishing resources in the study area. Species code: Table 1.

with $\mathrm{TL}<\mathrm{TL}_{50}$. For gillnets, nearly $60 \%(10 / 17)$ of the resources presented 'Min TL G/TL $\mathrm{TL}_{50}$ ' $\geq 1$, and probably were not caught before the first maturation. However, $40 \%$ (7 resources) presented Min TL $\mathrm{G}<\mathrm{TL}_{50}$ and were vulnerable to gillnets in juvenile conditions (Figure 6). 
Fishing resources caught of undersized for legal capture and/or before the first maturation constitute incidental capture in such gear. In trawling, size bycatch affects Genidens barbus, Centropomus undecimalis, Scomberomorus brasiliensis, Menticirrhus americanus, M. littoralis, M. furnieri, and Selene setapinnis; in gillnets, $S$. brasiliensis $M$. americanus, M. furnieri, Centropomus parallelus, Trichirus lepturus, Carcharhinus sp., Paralichthys sp., Prionotus punctatus, Larimus breviceps, Cynoscion guatucupa, and C. acoupa are affected (Figures 5 and 6).

\section{DISCUSSION}

Data showed that trawlers catch thrice the number of species than gillnetters, which reflects different selectivity between the two gears (Armstrong et al. 1990; Alarcón Vélez et al. 2014), as well as the mode and depth of operation. Active fishing, which is independent of fish movements and explores shallow waters, are the advantages of shrimp trawling, which result in higher yields than gillnets, which frequently work at the bottom up to $30 \mathrm{~m}$ depth (Chaves and Robert 2003; Afonso and Chaves 2021). Previous studies have pointed out a bathymetric heterogeneity in fish size distribution, with smaller individuals occupying mostly shallower waters, while larger ones occupy deeper waters. A similar trend was reported by Macpherson and Duarte (1991), who referred to demersal fish in the SE Atlantic (44 species) and the NW Mediterranean (31 species). This was also observed in the pelagic tuna fishery in Asia (FAO 2016). The size-depth relationship associated with gear selectivity helps to explain the size differences between captures from the gears, the smallest TL of $36 \mathrm{~mm}$ was found for trawling, and $100 \mathrm{~mm}$ for gillnets. Even so, the range of minimum TL of species caught by gillnets reached $610 \mathrm{~mm}$, which is an important value in view of their high selectivity. This is due to the multiple mesh sizes found in setnets plus driftnets, from 5 to $20 \mathrm{~cm}$ between opposite knots, exceptionally up to $45 \mathrm{~cm}$, operating simultaneously and/or alternately along the year (Chaves and Robert 2003; Afonso and Chaves 2021).

The minimum size of legal capture (TL C) is normally determined based on the reproductive condition, for example, the smallest mature fish, the average size of maturation $\left(\mathrm{TL}_{50}\right)$, or the size at which $100 \%$ of fish are mature (Sunil Mohamed et al. 2014). When TL $C$ is larger than $\mathrm{TL}_{50}$, it denotes caution in fisheries management. In the present work, $\mathrm{TL}_{50}$ was estimated for some species, and TL C was established for a lower number of resources. The values of these parameters are derived from various regions on the Brazilian coast, and in certain species both TL $\mathrm{C}$ and $\mathrm{TL}_{50}$ refer to two different stocks. Although not definitive, results indicate undersized individuals in bycatch that also occur in gillnets in the study area. The size at first maturation exceeded the maximum size caught by trawling in eight species, as well as the minimum size caught by gillnets in nine species. This means that undersized fish are caught by trawling (as expected) as well as by gillnets. Both conditions simultaneously apply to four species: G. barbus, S. brasiliensis, M. furnieri, and Macrodon ancylodon. These species play an important role in landings in Southern Brazil (MMA 2005; Chaves and Silva 2019; Chaves et al. 2021), and juveniles are being exploited by both trawling and gillnets. Because more species are caught by trawling, this gear acts on more undersized species than gillnets. However, relative to the number of species occurring in each gear, the size bycatch from gillnets is significant.

Capture of resources smaller than $\mathrm{TL}_{50}$ by gillnets in Brazilian waters has long been reported. Alves et al. (2012) studied mesh sizes of 7-13 cm and found undersized individuals in five of six species, including S. brasiliensis and M. furnieri. The status of the other three species recognized in the present work as occurring in gillnets is unknown because of the lack of data on TL C or 
$\mathrm{TL}_{50}$. Indeed, there are resources (e.g., Centropomus undecimalis and Menticirrhus littoralis) that also occur in gillnets (Afonso and Chaves 2021), but were not presented here because data on Min. TL G were not available.

The number and biomass in captures were not considered, nor were the discards accomplished on board in the case of commercial samplings. It is expected that in a single haul of trawling, a significant number of small fish were caught than with a similar effort using gillnets. On the other hand, considering the large area used to deploy gillnets (thousands of meters), and their period of exposure (up to six days fulltime), the total fishing effort of gillnets is intense, and the impact of gillnets on juveniles and undersized fish is not negligible. In the study area, SSF is only managed with respect to trawling; there are no policies on gillnet effort with respect to extension, time of exposure, or management by quotas. Only a few resources are subject to local rules disposing on the non-capture of young or of adults in the spawning period (Chaves and Silva 2019), and on the capture of threatened elasmobranchs (Chaves et al. 2019). In view of the occurrence of threatened teleost species in the study area, Afonso and Chaves (2021) recommended an effort reduction of gillnet with a mesh size of $18 \mathrm{~cm}$ at the end of winter and spring. Santurtún et al. (2014) stated that, for stocks that are not managed by quota, the biggest problem was discards due to minimum landing size, an alert that highlights the relevance of the present findings with respect to size bycatch in gillnets.

In the present work, gillnet captures were not individualized by mesh size, an omission that prevents an accurate analysis of the gear types most implied in non-target captures. Measures to reduce the capture of undersized fish, proposed by Alarcón Vélez et al. (2014), include the turnover of fishing areas and the extension of close seasons for fishing, taking into account the presence of juveniles. Alves et al. (2012) added that gillnet management should consider the earlier period of the reproductive cycle, since ovari- an development increases the fish perimeter at the first dorsal fin in $M$. furnieri and other teleosts. The influence of the reproductive cycle on mesh size selectivity, first described by McCombie and Berst (1969), affects adult fish, but is usually ignored in fishery rules.

This work highlights the suggestion of Cardoso et al. (2021) with respect to catches, and the partial discarding of fish that could be caught in bigger sizes and provides higher yields. It applies not only to fish and shrimp trawlings, but also to gillnets. Furthermore, from a global conservation perspective, gillnets affect vertebrates such as sharks, turtles, mammals, and penguins and other birds, when migrating in waters exposed to setnets and driftnets (Cheng and Tien-Hsi 1997; FAO 2020), presenting a strong challenge for monitoring and control. Following Santurtún et al. (2014), in view of the size bycatch existing in both trawling and gillnets, it is recommended to implement landing obligations for all catches, except for species with a high survival rate after release. According to these authors, time can be provided to fishers' organizations to develop innovative solutions to trade these undersized fish, or to find processed products that use the otherwise discarded fish as raw material.

\section{ACKNOWLEDGMENTS}

Author is grateful to three anonymous referees, and to the MAFIS Editor, by the time they have consecrated to the manuscript, and to the Matinhos fishers, by their assistance for data collection.

\section{REFERENCES}

Afonso MG, Chaves PT. 2021. A pesca de emalhe costeiro de pequena escala no litoral do Paraná: um estudo de caso para a conservação. 
Rev CEPSUL Biodiv Cons Mar. 10: e2021001. doi:10.37002/revistacepsul.v10. $1754 \mathrm{e} 2021001$

Alarcón Vélez JR, Salazar Céspedes CM, Guevara Carrasco R, Aubone A, Chacón G, Cornejo R, Garcia JC, Hanoza F, et al. 2014. Experiencias de selectividad con red de arrastre de fondo utilizando grillas de selección aplicado a la merluza peruana (Merluccius gayi peruanus). Rev Invest Desarr Pesq. 25: 83-95.

Alves PMF, Arfelli CA. Tomás ARG. 2012. Selectivity of bottom gillnet of Southeastern Brazil. Bol Inst Pesca. 38 (4): 275-284.

Armstrong DW, Ferro RST, MacLennan DN, REEves AS. 1990. Gear selectivity and the conservation of fish. J Fish Biol. 37 (A): 261262.

Braun AS, Fontoura NF. 2004. Reproductive biology of Menticirrhus littoralis in Southern Brazil (Actinopterygii: Perciformes: Sciaenidae). Neotrop Ichthyol. 2: 31-36. doi:10. 1590/S1679-62252004000100005

CARdoso LG, Bugoni L, Mancini L, Haimovici M. 2011. Gillnet fisheries as a major mortality factor of Magellanic penguins in wintering areas. Mar Pollut Bull. 62: 840-844. doi:10.1016/j.marpolbul.2011.01.033

Cardoso LG, Monteiro DS, Haimovici M. 2021. An assessment of discarded catches from the bottom pair trawling fisheryin southern Brazil. Mar Fish Sci. 34 (2): 197-210. doi:10.47193/mafis.3422021010609

Chaves PTC, Almeida MP, Platner M. 2019. Tubarões e raias como captura incidental na pesca artesanal do litoral do Paraná: condição reprodutiva e variações sazonais em composição e abundância. Arq Cien Mar. 52: 7-23.

Chaves PTC, Nogueira AB. 2018. Biologia reprodutiva do robalo-peva, Centropomus parallelus (Teleostei), na Baía de Guaratuba (Brasil). Acta Biol Paran. 47: 69-84.

Chaves P, Robert MC. 2003. Embarcações, artes e procedimentos da pesca artesanal no litoral sul do Estado do Paraná, Brasil. Atlantica. 25: 53-59.

Chaves PT, Silva AVF. 2019. Recursos-alvo que são também bycatch, e recomendação para a gestão da pesca de emalhe no litoral do Paraná, Brasil. Rev CEPSUL Biodiv Cons Mar. 8: 1-11. https://doi.org/10.37002/revistacepsul. vol8.732e2019001

Chaves PTC, Vaz-dos-Santos AM, Birnfeld PO. 2021. Population dynamics of Scomberomorus brasiliensis from a small-scale fishery of the Southwestern Atlantic Ocean. Ocean Coast Res. 69: 1-17. doi:10.1590/26752824069.20-016pdtdcc

Cheng JJ, Tien-Hsi C. 1997. The incidental capture of five species of sea turtles by coastal setnet fisheries in the eastern waters of Taiwan. Biol Conserv. 82: 235-239.

Colonello JC, Menni RC. 2011. Reproductive biology of the lesser guitarfish Zapteryx brevirostris from the south-western Atlantic Ocean. J Fish Biol. 78: 287-302. doi: 10.1111/j.10958649.2010.02864.x

Del Puente SV, Chaves P. 2009. Atividade reprodutiva do peixe-espada, Trichiurus lepturus (Teleostei), vulnerável à pesca de pequena escala no extremo-norte do litoral de Santa Catarina, Brasil. Biotemas. 22: 77-84.

[FAO] FoOd AND Agriculture ORganization of THE United NATiOnS. 2016. Technical and socio-economic characteristics of small-scale coastal fishing communities, and opportunities for poverty alleviation and empowerment, by Uwe Tietze. FAO Fisheries and Aquaculture Circular. 1111. 136 p.

[FAO] FoOd ANd Agriculture Organization OF the United Nations. 2020. Report of the expert meeting to develop technical guidelines to reduce bycatch of marine mammals in capture fisheries. Rome, Italy, 17-19 September 2019. FAO Fisheries and Aquaculture Report. 1289. 85 p. doi: $10.4060 / \mathrm{ca} 7620 \mathrm{en}$

Freiría J, Chocca JG, Marin Y, Gonzalez B, Beathyate G. 2014. Diseño y ensayo de redes 
de arrastre de fondo orientadas al escape de juveniles. Rev Invest Desarr Pesq. 25: 59-73.

Froese R, Pauly D. Editors. 2021. FishBase. https://www.fishbase.org.

Hout A, Paighambari SY, Eighani M, BroadHURST MK, BAYSE SM. 2021. Utility of gillnets for selectively targeting penaeids off Iran. Aquaculture and Fisheries. doi:10.1016/j.aaf. 2021.02.002

Huse I, Løkkeborg S, Soldal AV. 2000. Relative selectivity in trawl, longline and gillnet fisheries for cod and haddock. ICES J Mar Sci. 57: 1271-1282. doi:10.1006/jmsc. 2000. 00813

KALAYCI F, YeşILÇIÇEK T. 2014. Effects of depth, season and mesh size on the catch and discards of whiting (Merlangius merlangus euxinus) gillnet fishery in the Southern Black Sea, Turkey. Turk J Fish Aquat Sci. 14: 449-456. doi:10.4194/1303-2712-v14_2_15

Macpherson E, Duarte CM. 1991. Bathymetric trends in demersal fish size: is there a general relationship? Mar Ecol Prog Ser. 71: 103-112.

McCombie AM, Berst AH. 1969. Some effects of shape and structure of fish on selectivity of gillnets. J. Fish Res Board Can. 26 (10): 26812689. doi:10.1139/f69-260

Misund OA, Kolding J, Fréon P. 2002. Fish capture devices in industrial and artisanal fisheries and their influence on management. In: HART PJV, REYNOLDS JD, Editors. Handbook of fish biology and fisheries. Vol. 2. Fisheries. Malden: Blackwell Publishing, p. 13-36. doi:org/10.1002/9780470693919.ch2

MMA 2005. Instrução Normativa MMA, de 22 de novembro de 2005. Estabelece o tamanho mínimo de captura de espécies marinhas e estuarinas do litoral sudeste e sul do Brasil. Diário Oficial da União, Brazil, 24/November/2005.

MMA 2006. Instrução Normativa IBAMA, de 5 de janeiro de 2006. Proíbe, no Município de Canavieiras, no Estado da Bahia, a captura, o desembarque, o transporte, o armazenamento, o beneficiamento e a comercialização das espécies que especifica. Diário Oficial da União, Brazil, 05/January/2006.

Muniz E, Chaves PT. 2008. Condição reprodutiva da betara preta, Menticirrhus americanus (Teleostei, Sciaenidae), na pesca realizada no litoral norte de Santa Catarina, Brasil. Acta Sci Biol Sci. 30 (4): 339-344. doi:10.4025/actascibiolsci.v30i4.1230

Nogueira AB, Chaves PT, Robert MC, Aguiar KD. 2011. Participação da fisiografia local na composição dos atributos e estratégias de pesca no sul do Brasil. Bol Inst Pesca. 37: 13-30.

Olin M, Malinen T. 2003. Comparison of gillnet and trawl in diurnal fish community sampling. Hydrobiologia. 506-509: 443-449.

Pina JV, Chaves P. 2009. Incidência da pesca de arrasto camaroeira sobre peixes em atividade reprodutiva: uma avaliação no litoral norte de Santa Catarina, Brasil. Atlantica. 31: 99-106.

Pinheiro E. 2016. Atividade reprodutiva de peixes no arrasto camaroeiro: algo mudou após dez anos? Monografia apresentada como requisito parcial para obtenção do título de Bacharel em Ciências Biológicas, Setor de Ciências Biológicas, Universidade Federal do Paraná. Curitiba, 46 p.

Reis EG, PAwson MG. 1999. Fish morphology and estimating selectivity by gillnets. Fish Res. 39 (3): 263-273. doi:10.1016/S01657836(98)00199-4

Robert MC, Souza MAM, Chaves PTC. 2007. Biologia de Paralonchurus brasiliensis (Steindachner) (Teleostei, Sciaenidae) no litoral sul do Estado do Paraná, Brasil. Rev Bras Zool. 24: 191-198.

Romero RM, Moraes L, Santos M, Rocha G, CETRA M. 2008. Biology of Isopisthus parvipinnis: an abundant sciaenid species captured bycatch during sea-bob shrimp fishery in Brazil. Neotrop Ichthyol. 6: 67-74.

Santurtún M, Prellezo R, Arregi L, Iriondo A, Aranda M, Korta M, Onaindia I, Garcia D, Merino G, Ruiz J, Andonegi E. 2014. 
Characteristics of multispecific fisheries in the European Union. Directorate-General for Internal Policies, Policy Department B: Structural and Cohesion Policies, Fisheries. Brussels: European Parliament. 98 p.

Silva-JúNior CA, Viana AP, FrÉdou FL, FrÉDOU

T. 2015. Aspects of the reproductive biology and characterization of Sciaenidae captured as bycatch in the prawn trawling in the northeastern Brazil. Acta Sci-Biol Sci. 37: 1-8. doi:10. 4025/actascibiolsci.v37i1.24962

Silvano AM, Hallwass G, Juras A, Lopes PFM. 2016. Assessment of efficiency and impacts of gillnets on fish conservation in a tropical freshwater fishery. Aquat Conserv Mar Freshw Ecosyst. doi:10.1002/aqc.2687

Souza LM, Chaves P. 2007. Atividade reproduti- va de peixes (Teleostei) e o defeso da pesca de arrasto no litoral norte de Santa Catarina, Brasil. Rev Bras Zool. 24: 1113-1121.

Sunil MoHamed K, Zacharia PU, MaHESWARUdU G, Sathianandan TV, ABdusSamad EM, Ganga U, Lakshmi Pillai S, Sobhana KS, Rekha J, JosileEn J, et al. 2014. Minimum Legal Size (MLS) of capture to avoid growth overfishing of commercially exploited fish and shellfish species of Kerala. Mar Fish Info Serv T \& E Ser. 220. 5 p.

WolfF M, TAylor H, Tesfaye G. 2015. Implications of using small meshed gillnets for the sustainability of fish populations: a theoretical exploration based on three case studies. Fish Manag Ecol. 22: 379-387. doi:10.1111/fme. 12137 